\title{
Prevalence of Pneumatized Articular Eminence of the Temporal Bone and Its Importance in Maxillofacial Surgery
}

\section{Temporal Kemikte Pnömatize Artiküler Eminens Prevelansı ve Maksillofasiyal Cerrahideki Önemi}

\author{
(1) Utkan Kamil Akyol ${ }^{1}$, (1) Berrin Örs Oruğ² \\ ${ }^{1}$ Recep Tayyip Erdoğan University Faculty of Dentistry, Department of Oral and Maxillofacial Surgery, Rize, Turkey \\ ${ }^{2}$ Atasehir Oral and Dental Health Hospital, Clinic of Periodontology, İstanbul, Turkey
}

Keywords

Pneumatized articular eminence, maxillofacial surgery, temporomandibular joint surgery

\begin{abstract}
Anahtar Kelimeler
Pnömatize artiküler eminens, maksillofasiyal cerrahi, temporomandibular eklem cerrahisi
\end{abstract}

Received/Geliş Tarihi : 27.04.2017

Accepted/Kabul Tarihi : 22.06.2017

doi:10.4274/meandros.18209

Address for Correspondence/Yazışma Adresi: Utkan Kamil Akyol MD,

Recep Tayyip Erdoğan University Faculty of Dentistry, Department of Oral and Maxillofacial Surgery, Rize, Turkey

Phone : +90 5334678729

E-mail : utkankamilakyol@yahoo.com ORCID ID: orcid.org/0000-0002-4288-2887

CCMeandros Medical and Dental Journal, Published by Galenos Publishing House.

This is article distributed under the terms of the Creative Commons Attribution NonCommercial 4.0 International Licence (CC BY-NC 4.0).

It was presented as an oral presentation at $1^{\text {st }}$ International ORAD Congress (18.11.2016)

\begin{abstract}
Objective: Pneumatization is the presence of air filled cavities in a bone. They are seen in the root of the zygomatic arch of the temporal bone and in the articular eminence. The aim of this research was to determine the prevalence and type of pneumatized articular eminence of the temporal bone (PAT) among the patients of the dental clinic and to explain its importance in maxillofacial surgery.

Materials and Methods: Analysis of 8400 panoramic radiographs was performed. Age and sex of all the patients were recorded.

Results: PAT was discovered in 334 patients, accounting for prevalence of $3.9 \%$. For these 334 patients, $138(41.3 \%)$ were male and 196 (58.7\%) were female. Two hundred ninety (65.6\%) occurred unilaterally and 115 (34.4\%) bilaterally. Two hundred fifty one (55.9\%) of PAT presented with multilocular type, $182(40.5 \%)$ with unilocular type, and 16 (3.5\%) with trabecular appearance. In 194 (58\%) cases, PAT was located between the deepest point of the glenoid fossa to the crest of the articular eminence (grade 2), and in $140(42 \%)$ cases, PAT extended beyond the crest of the articular eminence (grade 3). PATs were found more common in females in the third decade of life.

Conclusion: Due to the fragile nature of these defect, surgeons who are planning to carry out temporomandibular joint surgery should be extra cautious when dealing with pneumatized articular eminence especially in third decade female people in population.
\end{abstract}

Öz

Amaç: Pnömatizasyon, bir kemikte hava dolu kavitelerin varlı̆ı̆dır. Temporal kemikte, zigomatik ark kökü ve artiküler eminenste görülebilirler. Bu çalışmanın amacı diş kliniği hastaları içinde temporal kemikte pnömatize artiküler eminens (PAT) prevalansını ve tiplerini saptamak ve maksillofasiyal cerrahideki önemini vurgulamaktır.

Gereç ve Yöntemler: Sekiz bin dört yüz panoramik radyografinin analizi yapıldı. Tüm hastaların yaş ve cinsiyetleri kaydedildi.

Bulgular: Üç yüz otuz dört hastada PAT görüldü ve prevalansı \%3,9 olarak hesaplandı. Bu 334 hastanın 138'i $(\% 41,3)$ erkek, 196'sı $(\% 58,7)$ kadındı. i̇ki yüz dokuz PAT $(\% 62,5)$ tek taraflı, $115(\% 37,5)$ bilateraldi. Multiloküler tip $251(\% 57,1)$, uniloküler tip $172(\% 39,1)$ ve trabeküler tip olarak $16(\% 3,6)$ PAT mevcuttu. Yüz doksan dört $(\% 58,0)$ PAT olgusu glenoid fossanın en derin noktası ile artiküler eminens arasında 
(2. derece) ve 140 (\%42) tanesi artiküler eminens krestasını aşmış durumdaydı (3. derece). Yaşamın üçüncü dekatındaki kadınlarda PAT daha yaygın olduğu görüldü.

Sonuç: Bu defektlerin kırılgan doğası nedeniyle, temporomandibular eklem cerrahisi yapmayı planlayan cerrahlar özellikle popülasyon içinde üçüncü dekattaki kadınlarda daha dikkatli olmalıdırlar.

\section{Introduction}

Pneumatization is the presence of air filled cavities in a bone. Zygomatic air cell defect or pneumatized articular eminence is a variant of normal anatomy. They are seen in the root of the zygomatic arch of the temporal bone and in the articular eminence (1). The pneumatized articular eminence of the temporal bone (PAT) identified as an asymptomatic radiolucent defect in the articular eminence of the temporal bone without cortical destruction $(2,3)$. PAT is not common but when present, it may be a complication for maxillofacial surgery (2). It is important to know PATs prevalence, unilateral or bilateral occurrence, and its grade for the follow-up of the pathologies that seen in the same area and for planning the maxillofacial surgery. The recognition of PATs is important in maxillofacial diagnosis and surgery. Our purpose was to determine the prevalence and type of PAT among the patients of the dental clinic and to explain its importance in maxillofacial surgery.

\section{Materials and Methods}

Panoramic radiographs were obtained on newly accepted outpatients attending the Ataşehir Oral and Dental Health Hospital during the period of 2012-2014. Panoramic images were obtained using a Planmeca Promax Digital Panoramic X-ray unit (Planmeca Inc., Helsinki, Finland). Eight thousand four hundred panoramic radiographs were evaluated in the present retrospective study. Radiographs were studied by two investigators. They used the same standard Planmeca Romexis software programme. Panoramic radiographs in which the zygomatic arch was not seen clearly and cases with previous history of maxillofacial fractures or had maxillofacial anomalies were excluded from our study. Diagnosis of PAT was done by well-defined radiolucency. Age and sex of all the patients were recorded. PAT was classified based on:

1. Age and gender;

2. Laterality: Unilateral or bilateral;

3. Appearance: Unilocular, multilocular, trabecular (multilocular with internal bony striations);
4. Grade: The mastoid and zygomatic arch pneumatization degree were classified according to panoramic finding:

a. Grade 0: The air cells are only in the mastoid process;

b. Grade 1: The air cells extended between the mastoid process and the deepest point of the glenoid fossa;

c. Grade 2: The air cells extended from the deepest point of the glenoid fossa to the crest of the articular eminence;

d. Grade 3: The air cells extended beyond the crest of the articular eminence.

\section{Statistical Analysis}

The data were analyzed using SPSS 11.5 (SPSS Benelux, Gorinchem, The Netherlands) computer software. The statistics methods used were mean and standard deviation.

\section{Results}

Eight thousand four hundred panoramic radiographs were investigated. Patients mean age was 32.8 years. The age range of the patients was between 10 and 60 years. Four thousand four hundred (52.3\%) male and 4000 (47.6\%) female patients were included in this study. The mean age of male and female patients was 32.6 and 33.1 years, respectively. PAT was observed in 334 patients, accounting for prevalence of $3.9 \%$ (Figure 1). For these 334 patients, 138 (41.3\%) were male and 196 (58.7\%) were female. Two hundred nineteen $(65.6 \%)$ occurred unilaterally and 115 (34.4\%) bilaterally. Two hundred fifty one (55.9\%) of PAT presented with multilocular type, 182 (40.5\%) with unilocular type and 16 (3.5\%) with trabecular appearance. A hundred ninety four (58\%) cases of PAT was located between the deepest point of the glenoid fossa to the crest of the articular eminence (grade 2) and in 140 (42\%) cases of PAT extended beyond the crest of the articular eminence (grade 3 ). PATs were more common in females in the third decade of life. 


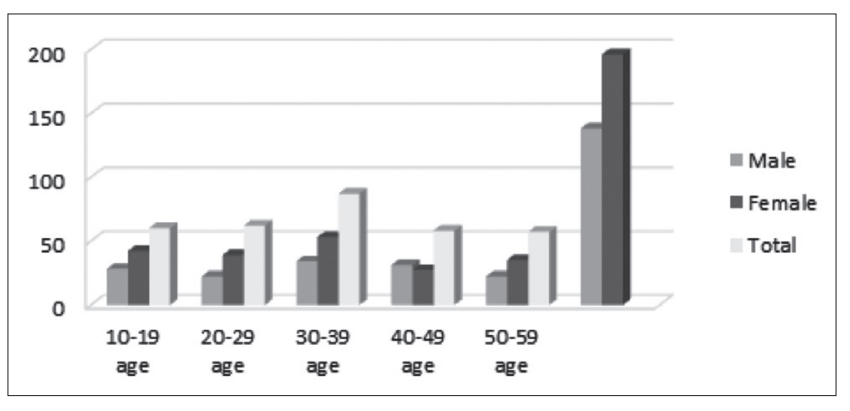

Figure 1. Age distribution of pneumatized articular eminence of the temporal bone patients by decade

\section{Discussion}

The prevalence of PAT in our study was 3.9\%, which is a higher prevalence rate compared to most of the studies in literature. Wide prevalence range of PAT, between $1 \%$ and $8 \%$, was observed in previous studies. The age range of the patients included in the studies, also, was very wide (4-81 years) (4-9). It is unknown at what age PATs begin to develop. According to some studies, PATs begin to pneumatize after puberty and after a few years they get full size $(10,11)$. Park et al. (12) suggested that, detection of PAT decreases after the age of 60 years. Therefore, patients aged between 10 and 60 years were included in our study. The mean age range in the studies for PAT occurrence have been reported between 30 and 49.6 years $(2,4,6-$ 8). In this study, the mean age of patients with PAT was 35.4 years. PATs were found more common in females in the third decade of life. Compared with previous studies, our sample number was greater (4-9). The male to female ratio was relatively equal. In our patients, PAT prevalence was similar in both sex (Male:Female 1.4:1), and the difference was not statistically significant. In one study, male to female ratio was 1:1.7 with a higher occurrence of PAT in female (6). Whereas, a higher male occurrence of PAT was found in Park et al.'s (12) study. Most of the previous studies revealed that PAT frequently occur unilaterally (5). In the present investigation, among the PATs, 219 (65.6\%) detected unilaterally and 115 (34.4\%) bilaterally. The high incidence of unilateral PAT was consistent with other studies $(5,6,12)$. Different variations of PAT appearance have been shown in previous reports (13). In the present study, we found 251 (55.9\%) of PAT presented with multilocular type, 182 (40.5\%) with unilocular type and 16 (3.5\%) with trabecular appearance. We have noted the grading system for air cell pneumatization of temporal bone. Grade 0 and 1 could not be examined in panoramic radiography, since the posterior aspect of glenoid fossa is usually superimposed by adjacent structures. So we just reported grades 2 and 3. Observably, the highest incidence of air cells was that of grade 2 (194 of PATs) followed by grade 3 (140 of PATs).

It is important to know PATs prevalence, unilateral or bilateral occurrence, and its grade for the followup of the pathologies that seen in the same area and for planning the maxillofacial surgery. PAT must be differentiated from some other diseases that are involved in zygomatic process of temporal bone including fibrous dysplasia, aneurismal bone cyst, central hemangioma, metastatic tumors, eosinophilic granuloma and central giant cell tumor. Since, cortical enlargement has been seen radiographically in these lesions as well as in PAT $(2,12,14)$. Unlike PAT, these lesions incite symptoms like facial asymmetry, pain and edema over the zygomatic bone. PAT has been found to be potential pathway for the spread of pathological processes and infection. Otitis media or mastoiditis may involve the temporomandibular joint (TMJ) and ankylosis could be occurred as a result of this $(7,15-17)$. Additionally, we must keep in mind that fractures of the base of the skull may extend through the PAT and this could be destructive for glenoid fossa (18). PAT may be a contraindication for TMJ surgery (6). So it is necessary for surgeons to be more careful when doing mandibular condyle and articular eminence surgery. As mentioned in literature, careless penetration through the PAT can lead to dural tear and cerebrospinal fluid leakage $(3,4,6)$. If pneumatized articular eminence has large volume, it is a contraindication for performing eminoplasty or eminectomy (8). Bone height reduction operations of the articular eminence may lead to complication in the presence of large PATs (15). Surgeons who are planning to do TMJ surgery must be aware of the details of PAT (19). During the surgery, surgeons must be careful while using bone ablating instruments to avoid penetration through the PAT $(3,4,6,20)$. In the studies, they pointed out that dehiscence of the glenoid fossa or pneumatizations exposed during eminectomies resulted as herniation of soft tissue contents can serve as risks for cranial sepsis, middle ear infections and mastoid effusion $(4,19)$. 


\section{Conclusion}

In this study, PATs were found more common in the third decade of life with a $3.9 \%$ prevalence, and more in females. Therefore, due to the fragile nature of PAT, surgeons who are planning to carry out TMJ surgery should be extra cautious when dealing with PAT especially in female patients within the third decade of life.

Ethics

Ethics Committee Approval: Retrospective study. Informed Consent: Retrospective study.

Peer-review: Externally peer-reviewed.

\section{Authorship Contributions}

Concept: U.K.A., B.Ö.O., Design: U.K.A., B.Ö.O., Data Collection or Processing: U.K.A., B.Ö.O., Analysis or Interpretation: U.K.A., B.Ö.O., Literature Search: U.K.A., B.Ö.O., Writing: U.K.A., B.Ö.O.

Conflict of Interest: No conflict of interest was declared by the authors.

Financial Disclosure: The authors declared that this study received no financial support.

\section{References}

1. Beaumont GD. The effects of exclusion of air from pneumatized bones. J Laryngol Oto 1966; 80: 236-49.

2. Tyndall DA, Matteson RS. Radiographic appearance and population distribution of the pneumatized articular eminence of the temporal bone. J Oral Maxillofac Surg 1985; 43: 493-7.

3. Patil K, Mahima VG, Malleshi SN, Srikanth HS. Prevalence of zygomatic air cell defect in adults. A retrospective panoramic radiographic analysis. Eur J Radiol 2011; 81: 957-9.

4. Carter LC, Haller AD, Calamel AD, Pfaffenbach AC. Zygomatic air cell defect (ZACD). Prevalence and characteristic in a dental clinic outpatient population. Dentomaxillofac Radiol 1999; 28: 116-22.

5. Miloglu O, Yilmaz AB, Yildirim E, Akgul HM. Pneumatization of the articular eminence on cone beam computed tomography: Prevalence, characteristics and a review of the literature. Dentomaxillofac Radiol 2011; 40: 110-4.

6. Orhan K, Delilbasi C, Cebeci I, Paksoy C. Prevalence and variations of pneumatized articular eminence: A study from Turkey. Oral Surg Oral Med Oral Patol Oral Radiol Endod 2005; 99: 349-54.

7. Hofmann T, Friedrich RE, Wedl JS, Schmelzle R. Pneumatization of the zygomatic arch on pantomography. Mund Kiefer Gesichtschir 2001; 5: 173-9.
8. Kaugars GE, Mercuri LG, Laskin DM. Pneumatization of the articular eminence of the temporal bone: Prevalence, development, and surgical treatment. J Am Dent Assoc 1986; 113: 55-7.

9. Nascimento HA, Visconti MA, Macedo PD, Haiter-Neto F, Freitas $D Q$. Evaluation of the zygomatic bone by cone beam computed tomography. Surg Radiol Anat 2015; 37: 55-60.

10. Zamaninaser A, Rashidipoor R, Mosavat F, Ahmadi A. Prevalence of zygomatic air cell defect: Panoramic radiographic study of a selected Esfehanian population. Dent Res J 2012; 9: 63-8.

11. Ilguy $M$, Dolekoglu S, Fişekcioglu E, Ersan N, Ilguy D. Evaluation of Pneumatization in the Articular Eminence and Roof of the Glenoid Fossa with Cone-Beam Computed Tomography. Balkan Med J 2015; 32: 64-8.

12. Park YH, Lee SK, Park BH, Son HS, Choi M, Choi KS. Radiographic evaluation of the zygomatic air cell defect. Oral and Maxillofac Radiol 2002; 32: 207-11.

13. Kim J, Song SW, Cho JH, Chang KH, Jun B. Comparative study of the pneumatization of the mastoid air cells and paranasal sinuses using three-dimensional reconstruction of computed tomography scans. Surg Radiol Anat 2010; 32: 593-9.

14. Stoopler ET, Pinto A, Stanton DC, Mupparapu M, Sollecito TP. Extensive pneumatization of the temporal bone and articular eminence: An incidental finding in a patient with facial pain. Case report and review of literature. Quintessence Int 2003; 34: 211-4.

15. Gupta D, Nc R, Sheikh S, Pallagatti S, Goyal G, Singh R, Parnami P, Singh G. The prevalence, radiographic appearance, and characteristics of zygomatic air cell defects (ZACDs) in symptomatic temporomandibular joint disorder patients in North Indian population. Oral Maxillofac Surg 2014; 18: 453-7.

16. Kumar R, Hota A, Sikka K, Thakar A. Temporomandibular joint ankylosis consequent to ear suppuration. Indian J Otolaryngol Head Neck Surg 2013; 65: 627-30.

17. De Roo N, Van Doorne L, Troch A, Vermeersch H, Brusselaers N. Quantifying the outcome of surgical treatment of temporomandibular joint ankylosis: A systematic review and meta-analysis. J Craniomaxillofac Surg 2016; 44: 6-15.

18. Groell R, Fleischman B. The pneumatic spaces of the temporal bone: relationship to the temporamandibular joint. Dentomaxillofac Radiol 1999; 28: 69-72.

19. da Costa Ribeiro R, dos santos BJ Jr, Provenzano N, de Freitas $\mathrm{PH}$. Dautrey's procedure: an alternative for the treatment of recurrent mandibular dislocation in patients with pneumatization of the articular eminence. Int J Oral Maxillofac Surg 2014; 43: 465-9.

20. Çandırlı C, Gümrükçü Z, Altıntaş NY, Sezgin OS, Okatan BK. Temporomandibular eklemde görülen sinoviyal kondromatozis ve cerrahi tedavisi: Bir olgu sunumu. Atatürk Üniv Diş Hek Fak Derg 2015; 12: 40-4. 